\title{
THE
}

\section{Informing the Balanced Theory of Port Competitiveness Using Ambidextrous Supply Chain Strategy}

Mehmet G. Yalcin

University of Rhode Island, mgyalcin@uri.edu

Satya S. Chakravorty

Gawon Yun

University of Rhode Island

Follow this and additional works at: https://digitalcommons.uri.edu/cba_facpubs

The University of Rhode Island Faculty have made this article openly available. Please let us know how Open Access to this research benefits you.

This is a pre-publication author manuscript of the final, published article.

Terms of Use

This article is made available under the terms and conditions applicable towards Open Access Policy Articles, as set forth in our Terms of Use.

\section{Citation/Publisher Attribution}

Yalcin, M. G., Chakravorty, S. S., \& Yun, G. (2019). Informing the Balanced Theory of Port Competitiveness Using Ambidextrous Supply Chain Strategy. Transportation Journal, 58(1), 21-37. Retrieved from https://muse.jhu.edu/article/714422

Available at: https://muse.jhu.edu/article/714422 
Informing the Balanced Theory of Port Competitiveness using Ambidextrous Supply Chain Strategy

Mehmet G. Yalcin, Assistant Professor *

College of Business

University of Rhode Island

205 Ballentine Hall, 7 Lippitt Road, Kingston, RI 02881

mgyalcin@uri.edu 401-874-4247

Satya S. Chakravorty, Professor

Coles College of Business

Kennesaw State University

560 Parliament Garden Way, MD \#0404, Kennesaw, GA 30144

Gawon Yun, Ph.D. Candidate

College of Business

University of Rhode Island

216 Ballentine Hall, 7 Lippitt Road, Kingston, RI 02881

* Corresponding author 
Informing the Balanced Theory of Port Competitiveness (BTOPC) using Ambidextrous Supply Chain Strategy

Abstract

This study explores the conceptual investigational foundations of how two existing concepts of supply chain exploitative practices and supply chain explorative practices, together may further inform the balanced theory of port competitiveness (BTOPC). The defined and validated factors of the BTOPC (Hales et al. 2016; 2017) are further investigated via the lens offered by ambidextrous supply chain strategy which is defined and measured through the simultaneous practice of exploitative and explorative activities (Kristal et al. 2010). Exploratory nature of this study aims to help academics to further the theory of port competitiveness and assist practitioners in improving port management. Eight in-person interviews with practitioner and academic port experts were conducted in addition to follow-up telephone conversations. This study finds that supply chain exploitative and explorative practices indeed offer a unique vantage view for assessing the port competitiveness when utilizing the BTOPC factors.

Keywords

Balanced theory of port competitiveness (BTOPC), concept of ambidexterity (CoA), exploitation, exploration, improvement systems recovery (ISR)

Introduction 
The concept of ambidexterity (CoA) suggests that firms should find a way to effectively manage two orthogonal elements (Birkinshaw and Gupta 2013; O'Reilly and Tushman 2013; Turner et al. 2013) that are generally established in the literature as exploitation and exploration. Port operations may benefit from CoA when it is employed in conjunction with the balanced theory of port competitiveness (BTOPC) (Hales et al. 2016; 2017) that simultaneously considers the effect of port strategy on customers and investors to increase port competitiveness. CoA could shed further light into each of the ten factors presented in the port competitiveness model which in turn would help with management of the ports.

Port operations may be employing both exploitation and exploration type activities which is an approach that is employed in the supply chains (Kristal et al. 2010) where operations exploit extant resources that reside within the entity and also explore resources that reside outside the entity. This ambidextrous supply chain strategy is shown to help organizations with achieving greater levels of performance (Lee and Rha 2016; Rojo et al. 2016). Coupled with the BTOPC, this study explores the port supply chain from the lens of CoA.

Since the instrument to measure the BTOPC concept is empirically validated with a large-scale study (Hales et al. 2016), this study extends its efficacy for strategic decision making and management of the ports. In the later sections, literature review is followed with methodology and results. Then, discussion and implications of the findings precede the conclusions and limitations.

Literature Review

Port Competition and Competitiveness 
Researchers have studied factors which affect port competition and competitiveness in global seaports and the extant literature on port competition primarily focuses on examining the relationship between individual factors and port selection (Murphy et al., 1992; Yeo and Song, 2006 Yeo et al., 2008). Fleming and Baird (1999) identify influential factors to achieve the relative port competitiveness, which include port tradition and organization, port accessibility, state aids, port productivity, port selection preferences of carriers and shippers, and comparative locational advantage. Malchow and Kanafani (2004) find that geographical location of a port is the most crucial characteristic in port choice. Slack (2006) finds that price and service consideration of carriers are considered important in decision making while port infrastructure is of less importance. In the same vein, Ng (2006) suggests that as increase in demand for liner shipping boosts higher port competition, port competitiveness plays an important role in transshipment decisions. Ng (2006) finds that cost, time efficiency, geographical location, and service quality are identified as important factors in explaining port attractiveness in Northern European ports. In a similar sense, Cullinane et al. (2006) focus on customer facing factors to measure the relative competitiveness of two Chinese ports. Their findings indicate that government policy provides positive impact on increase in service demand at ports, and that advantages in its natural endowments, price and service quality bring port competitiveness. de Langen (2007) explains that both shippers and forwarders have similar selection criteria that is not tied to traditions or relations. However, interestingly, forwarders tend to be more price sensitive than shippers; that is, they are likely to accept lower service level if provided with lower price. Tongzon and Heng (2005) examine port operation efficiency can be achieved through private sector participation, which can increase port competitiveness. Furthermore, their 
result finds that adaptability to the customers' demand is also an important factor to obtain port competitiveness. Yeo et al. (2008) identify seven qualitative and quantitative factors that impact port competitiveness in the context of North-East Asia region. The authors find that with recently increasing importance on technology and information system, port competitiveness can be gained through efficient logistics systems. Yeo and Song (2006) empirically examine that the most competitive port has port location, facility, and service level as its strongest sources of competitiveness while the least competitive port has cargo volume and port expenses. This result provides insights to port operators and managers to consider the influential factors to maintain or improve their port competitiveness based on hierarchical importance. Unlike previous studies which mainly focus on customer and investor perspectives of port competitiveness, Wang et al. (2012) explains port competition in relation to cooperation. The result implies that under port competition, port cooperation by forming alliances can bring competitive advantage in port industry. Port cooperation through these alliances can increase port competitiveness by defending market share along with demand for schedule reliability and service differentiation (Zhang and Lam, 2014). da Cruz et al. (2013) further extend the literature by examining port competitiveness from a stakeholder perspective. They demonstrate that the stakeholder group including seaport users and seaport service providers prioritize key factors of port competitiveness in a different way. To be specific, while seaport users (shipping companies) rank vessel turnaround time as the most important factor, seaport service providers consider port facilities the most important.

The Balanced Theory of Port Competitiveness (BTOPC) 
A recent publication by Hales et al. (2016) further develops the literature on port competitiveness by integrating customer facing (volume) competitiveness and investor facing (investors) competitiveness in port management. Their theory identifies ten important factors which impact port competitiveness that attracts both customers and investors (see figure 1 in appendix). BTOPC claims to explain how actual port managers should make decisions. The extant research on port decisions either focus on attracting or satisfying customers or investors, but not both. BTOPC provides a theoretical framework to explain how port managers must consider both customers and investors in their decisions. Using ten factors, the theory postulates that higher levels of satisfaction of customers and investors leads to higher levels of port competitiveness. The framework was tested on 72 of the top container ports in the world and was externally validated through port rankings over the past seven years (Hales et al. 2017). This empirical test of the theory finds that port location and port reputation are considered most important in evaluating port competitiveness.

The Concept of Ambidexterity (CoA)

Ambidexterity idea was first identified by Duncan (1976) when organizations performed better after enabling two separate structures that focus on exploitation as well as exploration. Moving beyond the structural boundaries, ambidexterity-related research expanded in organizational behavior in the following decades (i.e. March 1991; Levinthal and March 1993; Ghoshal and Bartlett 1994; Tushman and O’Reilly 1996) and advanced into the established CoA transitioning into the new millennium (i.e. Gibson and Birkinshaw 2004; Birkinshaw and Gibson 2004; Raisch and Birkinshaw 2008; Raisch et al. 2009; Simsek 2009; Lavie et al. 2010). Further 
elaborations and dissemination of CoA (i.e. Birkinshaw and Gupta 2013; O'Reilly and Tushman 2013; Turner et al. 2013) helped growth and extension of the CoA into firm and supply chain performance (i.e. Tokman et al. 2007; Im and Rai 2008; Adler et al. 2009; Kristal et al. 2010; Blome et al. 2013; Narasimhan and Narayanan 2013; Lee and Rha 2016; Rojo et al. 2016).

\section{Ambidextrous Supply Chain Strategy and Ports}

Birkinshaw and Gupta (2013) suggest that ambidexterity is not necessarily opposing, but more orthogonal with synergistic relationships by arguing that while measuring exploitation and exploration separately is essential, they should not represent a strict trade-off. The study by Kristal et al. (2010) also emphasize a complementary relationship between efficiency and new visions by operationalizing the CoA with ambidextrous supply chain strategy with the elements of supply chain exploitative practices and supply chain explorative practices.

In this study, we adapt definitions from Kristal et al. (2010) and define port supply chain exploitation practices as “A port's efforts to refine and extend its existing resources" and accompanied with the following four measurement items: (i) In order to stay competitive, our port supply chain managers focus on reducing operational redundancies in our existing processes; (ii) Leveraging of our current port supply chain technologies is important to our firm's strategy; (iii) In order to stay competitive, our port supply chain managers focus on improving our existing technologies; (iv) Our port managers focus on developing stronger competencies in our existing port supply chain processes. On the other hand, we define port supply chain exploration practices as "A port’s efforts to develop new port supply chain competencies through experimenting and acquisition of new knowledge and resources" which are measured via: (i) We 
proactively pursue new port supply chain solutions; (ii) We continually experiment to find new solutions that will improve our port supply chain; (iii) To improve our port supply chain, we continually explore for new opportunities; (iv) We are constantly seeking novel approaches in order to solve port supply chain problems.

Similar to the competition focus of BTOPC, CoA explains how firms can be more competitive through higher levels of exploitation and exploration activities. This study examines the relationships between BTOPC and CoA to examine which activities of BTOPC are exploitative and which are explorative. This is important because the BTOPC only looks at rankings of the importance of each of the ten factors, and not in which activities a port may be weak. By viewing activities as either exploitive or explorative, CoA can guide port managers to develop strategies that are practical to strengthen their competitive position at a port-level. For example, a port looking to increase sales will use port supply chain exploration practices in the customer-facing competitiveness factors. Alternatively, a port wishing to reduce costs will conduct port supply chain exploitation practices in customer-facing factors. This first study focuses only on the customer-facing port supply chain exploitation and exploration practices because all of our respondents are experts in this area. We could not include investor-facing competitiveness because no major investors agreed to participate in our study.

\section{Methodology}

Eight in-depth interviews were conducted for this study where we followed the theoretical criteria suggested by Lincoln and Guba (1985) for the data collection step that includes: emergence of regularities, over-extension, saturation of categories, and exhaustion of sources. 
Emergence of regularities and exhaustion of sources were the signals for ending the data collection process. Due to lack of investor cooperation, investor competitiveness side of BTOPC (price, institutional structure, legal framework, financial resources, port reputation) was dropped from the analysis.

While the interviews were the primary source for data collection (Hatch 2002), secondary information was obtained by researching publicly available information about four major seaports where the respondents (port managers) worked. As the interview questions were openended, detailed explanations were enriched with the help of probing follow-up statements. This process ensured that the data collected differed significantly from a survey methodology which often times guides interviewees among standardized responses. The interviewers possessed scholarly knowledge about the ports however, they were provided with CoA related question pool by another researcher. This helped the interviewers to stay neutral and navigate throughout the interviews based on the respondent's answers through which further insight was extracted that would otherwise be inaccessible. The interview questions conformed to the guideline suggested by Hatch (2002, 106-107) which prescribes: neutrality, respectfulness to respondent and their knowledge, use of proper language, clarity, open-endedness, generation of relevant responses.

Extending CoA (Whetten 1989, 491) to port supply chain, the exploratory interviews enabled researchers to capture expert opinion about exploitative and explorative practices that are related to port competitiveness, and in particular, factors that are associated with the BTOPC. The unit of analysis was set at port-level where the semi-structured interviews were conducted with expert practitioners and academics who are involved in port operations and research. The interviewees 
were recruited at a major global port conference with the objective of generating exploratory insights and/or propositions that are related to real-world occurrences (Patton 2002, 489).

\section{Interview Participants}

The interviews took place in-person with four port managers, two carrier representatives, one shipper representative, and one international longshoreman association representative in summer 2017 and follow-up telephone interviews were conducted about two months later to validate the answers and also verify any feedback that were deemed uninterpretable during the analysis stage. McCracken (1988)'s minimum number of eight recommended interviews was satisfied in this exploratory study. As one researcher conducted the interviews following a semi-structured interview guide and taking notes, another researcher took notes of the responses as well as things that cannot be expressed in words such as facial mimics and body gestures. Interviews took about thirty minutes on average and for anonymity the respondents shown on Table 1 and 2 were coded with names of their workplaces without disclosing their names.

\section{$<$ TABLE 1>}

This study was conducted using four ports, two carriers, one shipper, and one supplier in Japan during the International Association of Maritime Economists (IAME 2017 Conference). While major global ports of Kobe (Japan), Busan (Korea), Qingdao (China), and Tokyo (Japan) were analyzed in this study, other major participants included Toyota (Shipper), International Longshoremen Association (ILA) (Supplier), Nippon Yusen Kabushiki Kaisha-NYK Lines 
(Carrier), and Mitsui O.S.K. Lines-MOL (Carrier). The interviewees were Port Directors (Assist, Assoc, Senior Managers), Shipper’s and Carriers’ AVP of Operations, and Supplier’s ILA Union Representative. The interviewees had direct knowledge of the strategies and activities conducted in their respective organizations; including the factors in the BTOPC and the explorative and exploitive activities. While all interviews were conducted at the IAME conference in Kyoto, Japan during the Summer of 2017, brief follow-up telephone conversations were made within two months of the initial in-person feedback from the interviewees.

The interviews consisted of two distinct steps. The first step of the study was to conduct face-to-face interviews collecting feedback regarding the factors of BTOPC. The respondents were asked to report key activities conducted in their organization within the last twelve months in each of the five factors of customer-facing competitiveness. A local translator was also present to assist in clarifying the questions and the responses. Coded responses are shown in Table 1.

Immediately after the responses were collected for each interviewee, the CoA was introduced in step two of the interview process and the definitions of port supply chain exploitation and exploration practices were presented to the respondents in writing. Although these definitions were provided in English, the translator assisted with clarification as needed. The respondents were then asked to classify the activities they identified in the first step as primarily exploitative (coded as EX), explorative (coded as ER), both (EX, ER), or neither (N). The study was conducted face-to-face because the CoA is not used in industry and required discussion before the managers felt that they understood the concept adequately. The coding results are presented in Table 2.

$<$ TABLE 2> 
Results and Findings

The following discussion of the results include the evidence in Table 1 and 2, as well as open comments by the respondents that we could not incorporate into a table.

Port Location

The port managers indicate that due to landside and channel depth restrictions, that exploiting the port location factor is not applicable. Exploration in this area would be to look for new areas to locate a port or expand an existing port. The ports in this study were not looking to explore new terminals. This is an anomaly of this convenience sample since ports like Singapore have relocated terminals for exploitation purposes.

\section{Port Facility}

The ports consider exploitation of port facilities as serving more customers and volume with the same level of infrastructure. Thus, when demand does not change, increase in the amount of space and the number of employees needed can indicate that the port is less efficient. The port of Tokyo and Busan practiced exploration through new innovative technology, which enabled handling more containers. Expanded use information technology (IT) at Tokyo was used to exploit existing infrastructure; whereas, significant IT upgrades coupled with infrastructure and superstructure improvements enhanced port capacity. However, the port of Kobe and Qingdao 
did not expand facilities through either exploitation or exploration of technology. The port of Qingdao practiced exploration by expanding to passenger and recreational vessels such as sailboats. The port of Busan was a prime example of exploration by building new port facilities in a different location on a larger scale than the port of Tokyo that followed similar strategy. However, a recent bankruptcy of the Hanjin Shipping Co. Ltd. negated the expected benefits to Busan.

At the time of this data collection the merger of K-Line, MOL and NYK had not finalized. NYK mentioned the possible merger in their responses and classified the joint use of Port Facility due to the merger as an explorative activity. Also, exploration by carriers would entail seeking ports with more efficient/higher capacity operations. MOL rated this as an exploitation activity. While shippers seek infrastructure development for just-in-time (JIT) performance, from a supplier side, the reduced number of personnel at ports can make operations run smoother and more manageable.

\section{Cargo Volume}

Tokyo and Busan demonstrated that they can exploit cargo volume due to excess capacity onhand. They have more capacity in crane and hinterland resources to handle double the cargo at this time. Even prior to the Hanjin bankruptcy and the slowing of global shipping, these ports had excess capacity. Kobe and Qing Dao had no appreciable change in cargo volume over this period. Carriers can exploit cargo volume to increase capacity utilization and explore by adding bigger or additional vessels to the routes if the port can handle larger volumes. The labor union can have considerable impact if they operate for 24 hours, seven days a week. After the merger 
of K-Line, MOL, and NYK, exploitation opportunities have expanded exponentially. It is interesting to note that all of the respondents reported using some form of Lean or Six Sigma practices to increase exploitation in cargo volume. They also reported limited long-term success using these practices and Qing Dao reported abandoning them at times. Given the decline in Korean ports, Qing Dao has restarted improvement practices under the umbrella of what they refer to as Improvement Systems Recovery (ISR), loosely translated from Chinese. We find no literature that examines ISR.

\section{Service Level}

The port of Tokyo and Kobe exploited their IT capability to maintain and/or increase the service level. The port of Tokyo especially improved its service level by extending efficiency instead of building extra infrastructure. While the port of Qingdao increased service level by exploration activities that served a new market of recreational vessels. They viewed this as an increase in service levels because it broadened the types of maritime they serve. In the Busan New Port, managers exploited the new terminals. Integration with port operators and the ILA labor union directly influences how much the service levels can be exploited. Toyota focused on continuous improvement opportunities with port related processes in order to exploit their JIT capabilities.

\section{Port Fees}

The port of Tokyo and Busan increased their revenues from port fees through exploitation by offering the full 24/7 service window. The on-peak pricing is also offered at Kobe and Qing Dao. 
Carriers also exploit the peak and off-peak pricing scheme by working with shippers and explore opportunities for volume discounts via reaching and updating pricing agreements. MOL had an activity they viewed as explorative by pricing based on parameters other than volume and timeof-day, but would not allow the authors to publish their approach. Toyota exploits port fees by shipping on off-peak and having dedicated terminals.

Discussion and Implications of the Findings

The results support the proposition that another dimension to BTOPC should be considered beyond application of the ten factors. The CoA can be applied to guide managers on which activities can be most beneficial at a port level, regardless of how the factors rank on the BTOPC. While it may apply to both costumer and investors, only customer-facing respondents participated in this study. The port supply chain exploitative practices are more prevalent than the port supply chain explorative practices. This makes sense since explorative practices at ports require new technologies, infrastructure, superstructure, or partners, which are very expensive to acquire. After reporting the results to the managers, they responded that they could use the information to justify more explorative activities at their port to increase competitiveness.

While this study is primarily conceptual and exploratory because of the novel approach of applying CoA to BTOPC, it does include some supporting interview data from relevant port and organizational managers. This study contributes to the literature by suggesting that the theory of port competitiveness can be informed through the application of CoA. This means that while the BTOPC explains two dimensions to managerial decisions by showing how they should 
consider both customers and investors in decision-making, mangers should also consider their ability to exploit existing capabilities or explore new capabilities to improve competitiveness.

The CoA view helped to classify activities that effect the BTOPC volume competitiveness factors from an overall strategic perspective. Practically, this means that managers can improve competitiveness by exploring new and innovative opportunities to improve Port Location, Port Facility, Cargo Volume, Service Levels, and Port Fees, or take better advantage of existing capabilities (exploit). Next, the CoA offers a simplified classification of the activities under three categories (exploitative, explorative, neither exploitative nor explorative) which would help managers establish and execute strategic port management plans through better resource allocation under these categories. Ports can quickly determine the BTOPC factors that are difficult to associate with sustained exploitative or explorative activities, such as Port Location. This knowledge can help port managers with avoiding investments with short-term impacts and also differentiate their ports from competition knowing how the other ports are handling their port activities.

Third, this study demonstrates another method of prioritizing the factors on which ports choose to focus their resources. The BTOPC promotes the use of the AHP weighting factors and suggests that port managers should prioritize investments based on these rankings. The CoA contributes to this by suggesting that managers can select either exploitative investments or explorative investments within each of the ten factors. Since the eight managers in this study report that explorative activities tend to be more expensive and take longer to identify and implement, CoA can be another method of ranking investments. 
Fourth, the CoA lens helps managers view the BTOPC factors in a way where opportunities for further competitiveness become more visible regardless of port size or type of port. Studying this concept in a larger sample of ports in various contexts is needed.

Conclusions and Limitations

The purpose of our research study is to further investigate the balanced theory of port competitiveness (BTOPC) (Hales et al. 2016; 2017) via the lens offered by ambidextrous supply chain strategy (CoA) which is defined and measured through the simultaneous practice of exploitative and explorative activities (Kristal et al. 2010). Exploratory nature of this study aims to help academics to further the application of theory of port competitiveness and assist practitioners in improving port management.

Using the port as the unit of analysis, we have observed that supply chain exploitation and exploration practices help inform the BTOPC. The CoA is utilized from port supply chain perspective and BTOPC is extended with added definition that can be used by researchers and port managers.

There are several limitations of this study. First, the interviews consist of single senior respondents from a convenience sample which didn’t captured the full range of port operations. Multiple respondents from the same port entity would have improved our study. Second, even though the interviews in this study represent major global seaports, because all of them are located in far-east Asia region, the number of interviews can be expanded into the other continents/areas of the globe. Third, and tied to the second point, naturally the interviewees were primarily representative of the practitioners and the academics who were based in the Asian ports 
and educational institutions. Although the respondents have strong ties with the global trade and other regions of the globe, the selection could be improved to enhance the generalizability of this study. Fourth, the measurement items for port supply chain exploitative and explorative practices were directly adapted from those that were developed for manufacturing firms. This requires further studies to examine if the measures should be redefined for ports. Fifth, this study only included five of the ten factors in the BTOPC, all of which measured Customer Competitiveness. Investor Competitiveness was not included and is problematic because investors are a significant factor is port decisions. Sixth, BTOPC informs the literature on CoA by applying it to a different context.

Appendix

$<$ FIGURE 1>

References

Adler, P. S., Benner, M., Brunner, D. J., MacDuffie, J. P., Osono, E., Staats, B. R., Takeuchi, H., Tushman, M. L., and S.G. Winter. 2009. "Perspectives on the productivity dilemma.” Journal of Operations Management 27(2): 99-113.

Birkinshaw, J., and C. Gibson. 2004. "Building ambidexterity into an organization.” MIT Sloan Management Review 45(4): 47.

Birkinshaw, J., and K. Gupta. 2013. "Clarifying the distinctive contribution of ambidexterity to the field of organization studies.” The Academy of Management Perspectives 27(4): 287-298. 
Blome, C., Schoenherr, T., and M. Kaesser. 2013. “Ambidextrous governance in supply chains: The impact on innovation and cost performance.” Journal of Supply Chain Management 49(4): 59-80.

Cullinane, K., Teng, Y., and T. F. Wang. 2006. "Port competition between Shanghai and Ningbo.” Maritime Policy \& Management 32(4): 331-346.

Duncan, R. B. 1976. “The ambidextrous organization: Designing dual structures for innovation.” The management of organization 1: 167-188.

Fleming, D. K., and A. J. Baird. 1999. “Comment Some reflections on port competition in the United States and western Europe.” Maritime Policy \& Management 26(4): 383-394.

da Cruz, M. R. P., Ferreira, J. J., and S. G. Azevedo. 2013. “Key factors of seaport competitiveness based on the stakeholder perspective: An Analytic Hierarchy Process (AHP) model” Maritime Economics \& Logistics 15(4): 416-443.

de Langen, P. W. 2007. "Port competition and selection in contestable hinterlands: the case of Austria.” European Journal of Transport and Infrastructure Research 7(1): 1-14.

Ghoshal, S., and C. Bartlett. 1994. "Linking organizational context and managerial action: The dimensions of quality in management.” Strategic Management Journal 15: 91-112.

Gibson, C. B., and J. Birkinshaw. 2004. "The antecedents, consequences, and mediating role of organizational ambidexterity.” Academy of Management Journal 47: 209-226.

Hales, D., Lam, J. S. L. and Y. T. Chang. 2016. “The Balanced Theory of Port Competitiveness.” Transportation Journal 55(2): 168-189. 
Hales, D. N., Chang, Y. T., Lam, J. S. L., Desplebin, O., Dholakia, N., and A. Al-Wugayan. 2017. “An empirical test of the balanced theory of port competitiveness.” The International Journal of Logistics Management 28(2): 363-378.

Hatch, J. A. 2002. Doing Qualitative Research in Education Settings, Albany, NY: SUNY Press.

Im, G., \& Rai, A. 2008. “Knowledge sharing ambidexterity in long-term interorganizational relationships.” Management Science 54: 1281-1296.

Kristal, M., Huang, X., and A. V. Roth. 2010. “The effect of an ambidextrous supply chain strategy on combinative competitive capabilities and business performance.” Journal of Operations Management 28: 415-429.

Lavie, D., Stettner, U., and M. L. Tushman. 2010. “Exploration and exploitation within and across organizations.” The Academy of Management Annals 4(1): 109-155.

Lee, S. M., and J. S. Rha. 2016. “Ambidextrous supply chain as a dynamic capability: building a resilient supply chain.” Management Decision 54(1): 2-23.

Levinthal, D. A., and J. G. March. 1993. “The myopia of learning.” Strategic Management Journal 14: 95-112.

Lincoln, Y. S., and E. G. Guba. 1985. Naturalistic inquiry, (Vol. 75). Sage.

Malchow, M. B., and A. Kanafani. 2004. “A Disaggregate Analysis of Port Selection.” Transportation Research Part E 40(4): 317-337.

March, J. G. 1991. “Exploration and exploitation in organizational learning.” Organization Science 2: 71-87. 
McCracken, G. 1988. The long interview, (Vol. 13). Sage.

Murphy, P., Daley, J., and D. Dalenberg. 1992. "Port selection criteria: an application of a transportation research framework.” Logistics and Transportation Review 28(3): 237-255.

Narasimhan, R., and Narayanan, S. 2013. "Perspectives on supply chain driven innovation.” Journal of Supply Chain Management 49 (4): 27-42.

Ng, A. K. 2006. “Assessing the Attractiveness of Ports in the North European Container Transhipment Market: An Agenda for Future Research in Port Competition.” Maritime Economics \& Logistics 8(3): 234-250.

O'Reilly, C. A., and M. L. Tushman. 2013. “Organizational ambidexterity: Past, present, and future.” The Academy of Management Perspectives 27(4): 324-338.

Patton, M. Q. 2002. “Two decades of developments in qualitative inquiry a personal, experiential perspective.” Qualitative Social Work 1(3): 261-283.

Raisch, S., Birkinshaw, J., Probst, G., and M. L. Tushman, M.L. 2009. “Organizational ambidexterity: Balancing exploitation and exploration for sustained performance.” Organization Science 20: 685-695.

Raisch, S., and J. Birkinshaw. 2008. “Organizational ambidexterity: Antecedents, outcomes, and moderators.” Journal of Management 34: 375-409.

Rojo, A., Llorens-Montes, J., and M. N. Perez-Arostegui. 2016. “The impact of ambidexterity on supply chain flexibility fit.” Supply Chain Management: An International Journal 21(4): 433452. 
Simsek, Z. 2009. “Organizational ambidexterity: Towards a multilevel understanding.” Journal of Management Studies 46(4): 597-624.

Slack, B. 2006. “Containerization, inter-port competition, and port selection.” Maritime Policy \& Management 12(4): 293-303.

Tokman, M., Richey, R. G., Marino, L. D., and K. M. Weaver. 2007. “Exploration, exploitation and satisfaction in supply chain portfolio strategy.” Journal of Business Logistics 28: 25-56.

Tongzon, J., and W. Heng. 2005. "Port privatization, efficiency and competitiveness: Some empirical evidence from container ports (terminals).” Transportation Research Part A: Policy and Practice 39(5): 405-424.

Turner, N., Swart, J., and H. Maylor. 2013. "Mechanisms for managing ambidexterity: a review and research agenda.” International Journal of Management Reviews 15(3): 317-332.

Tushman, M. L., and C. A. III O’Reilly. 1996. “Ambidextrous organizations: Managing evolutionary and revolutionary change.” California Management Review 38: 8-30.

Wang, K., Ng, A. K. Lam, J. S. L., and X. Fu. 2012. “Cooperation or Competition? Factors and Conditions Affecting Regional Port Governance in South China.” Maritime Economics and Logistics 14 (3): 386-408.

Whetten, D. A. 1989. "What constitutes a theoretical contribution?.” Academy of management review 14(4): 490-495.

Yeo, G., Roe, M., and J. Dinwoodie. 2008. "Evaluating the competitiveness of container ports in Korea and China.” Transportation Research Part A: Policy and Practice 42(6): 910-921. 
Yeo, G., and D. Song. 2006. “An application of the hierarchical fuzzy process to container port competition: Policy and strategic implications.” Transportation 33(4): 409-422.

Zhang, A., and J. S. L. Lam. 2014. "Impacts of Schedule Reliability and Sailing Frequency on the Liner Shipping and Port Industry: A Study of Daily Maersk.” Transportation Journal 53(2): $235-53$. 
Table 1/Respondent profile and post-analysis interview data

\begin{tabular}{|c|c|c|c|c|c|}
\hline \multirow[b]{2}{*}{ Interviewees } & \multicolumn{5}{|c|}{ BTOPC Volume Competitiveness } \\
\hline & Port Location & Port Facility & $\begin{array}{l}\text { Cargo } \\
\text { Volume } \\
\end{array}$ & Service Level & Port Fees \\
\hline \multicolumn{6}{|l|}{$\underline{\text { Port }}$} \\
\hline Tokyo & $\begin{array}{l}\text { Fully built available } \\
\text { land space, no } \\
\text { expansion } \\
\text { opportunity left }\end{array}$ & $\begin{array}{l}\text { Expanded through } \\
\text { technology (handle more } \\
\text { containers by integrating } \\
\text { more technology) } \\
\text { Amount of space/facility, } \\
\text { number of people }\end{array}$ & $\begin{array}{l}\text { Demonstrated } \\
\text { they handle } \\
\text { large volumes: } \\
4.5 \text { mil. } \\
\text { TEU/yr }\end{array}$ & $\begin{array}{l}\text { Use efficiency and } \\
\text { tech/automation to } \\
\text { improve service level } \\
\text { instead of increasing } \\
\text { extra capacity }\end{array}$ & $\begin{array}{l}\text { Peak/off-peak } \\
\text { pricing for } \\
\text { carriers and port } \\
\text { services ( } 24 / 7 \\
\text { service) }\end{array}$ \\
\hline Kobe & Similar to Tokyo & $\begin{array}{l}\text { Did not have much } \\
\text { expansion }\end{array}$ & $\begin{array}{l}\text { Not much } \\
\text { exploitation of } \\
\text { cargo volume }\end{array}$ & Similar to Tokyo & $\begin{array}{l}\text { Peak/off-peak } \\
\text { pricing for } \\
\text { carriers and port } \\
\text { services }\end{array}$ \\
\hline Qingdao & Similar to Tokyo & $\begin{array}{l}\text { More of } \\
\text { passenger/recreational } \\
\text { ports e.g. sailing }\end{array}$ & $\begin{array}{l}\text { Not much } \\
\text { exploitation of } \\
\text { cargo volume }\end{array}$ & $\begin{array}{l}\text { Increase service } \\
\text { capacity for their } \\
\text { recreational purpose }\end{array}$ & Similar to Kobe \\
\hline Busan & Similar to Tokyo & $\begin{array}{l}\text { Expanded through } \\
\text { technology (handle more } \\
\text { containers by integrating } \\
\text { more technology) }\end{array}$ & $\begin{array}{l}\text { Demonstrated } \\
\text { they handle } \\
\text { large volumes }\end{array}$ & $\begin{array}{l}\text { Intentionally creating } \\
\text { extra service capacity }\end{array}$ & Similar to Tokyo \\
\hline
\end{tabular}


Table 1/...continued

\begin{tabular}{|c|c|c|c|c|c|}
\hline \multirow[b]{2}{*}{ Interviewees } & \multicolumn{5}{|c|}{ BTOPC Volume Competitiveness } \\
\hline & Port Location & Port Facility & $\begin{array}{l}\text { Cargo } \\
\text { Volume } \\
\end{array}$ & Service Level & Port Fees \\
\hline \multicolumn{6}{|l|}{$\begin{array}{l}\text { Port } \\
\text { Carriers }\end{array}$} \\
\hline NYK & $\begin{array}{l}\text { Improve capacity } \\
\text { utilization for } \\
\text { existing routes based } \\
\text { on shipper profiles. } \\
\text { Find new routes that } \\
\text { reduce the cost of } \\
\text { business }\end{array}$ & $\begin{array}{l}\text { Improve existing } \\
\text { relationships with the } \\
\text { port operators and } \\
\text { stakeholders (i.e. labor } \\
\text { union) for more } \\
\text { efficiency } \\
\text { Seek more efficient ports } \\
\text { with higher capacity }\end{array}$ & $\begin{array}{l}\text { Increase } \\
\text { capacity } \\
\text { utilization } \\
\text { Add } \\
\text { bigger/addition } \\
\text { al vessels if } \\
\text { larger volumes } \\
\text { allowed }\end{array}$ & $\begin{array}{l}\text { Integrate with port } \\
\text { operators and labor } \\
\text { union } \\
\text { Flexibility through IT } \\
\text { improvements, } \\
\text { robustness and free } \\
\text { capacity of port } \\
\text { operations }\end{array}$ & $\begin{array}{l}\text { Leverage } \\
\text { peak/off-peak } \\
\text { pricing scheme. } \\
\text { Opportunities for } \\
\text { volume discounts } \\
\text { via pricing } \\
\text { agreements }\end{array}$ \\
\hline MOL & Similar to NYK & Similar to NYK & $\begin{array}{l}\text { Similar to } \\
\text { NYK }\end{array}$ & Similar to NYK & Similar to NYK \\
\hline \multicolumn{6}{|l|}{ Shipper } \\
\hline Toyota & $\begin{array}{l}\text { Change location and } \\
\text { roll-on/roll-off }\end{array}$ & $\begin{array}{l}\text { Developing infrastructure } \\
\text { for JIT performance }\end{array}$ & $\mathrm{n} / \mathrm{a}$ & Accommodate JIT & Cheaper the better \\
\hline \multicolumn{6}{|l|}{ Supplier } \\
\hline ILA Union & $\mathrm{n} / \mathrm{a}$ & $\begin{array}{l}\text { Have good relationships } \\
\text { with union }\end{array}$ & Operate 24/7 & $\begin{array}{l}\text { Paying more for } \\
\text { faster service }\end{array}$ & $\mathrm{n} / \mathrm{a}$ \\
\hline
\end{tabular}


Table 2/Coding* interview data through the lens of ambidextrous supply chain strategy

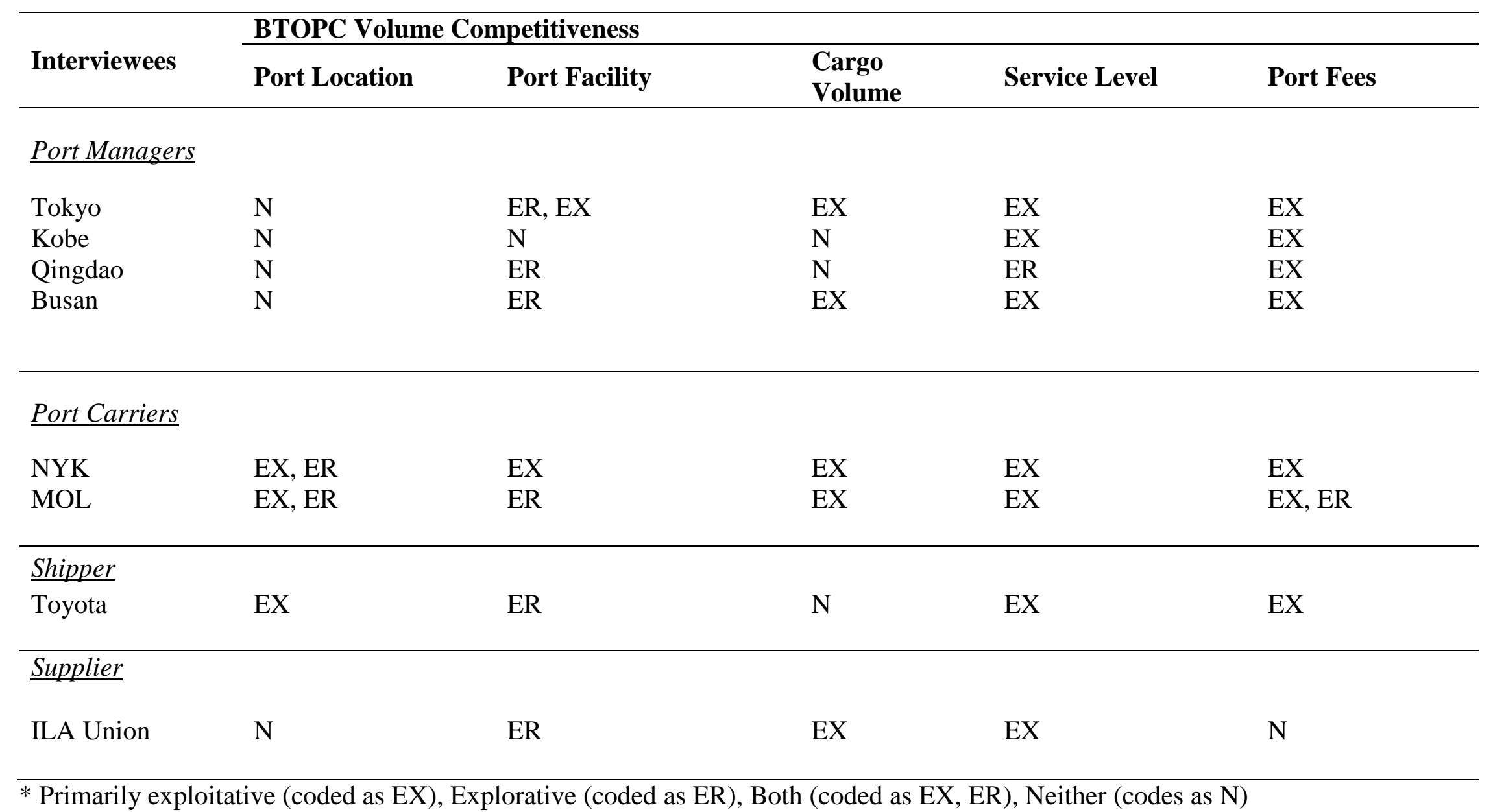

* Primarily exploitative (coded as EX), Explorative (coded as ER), Both (coded as EX, ER), Neither (codes as N) 


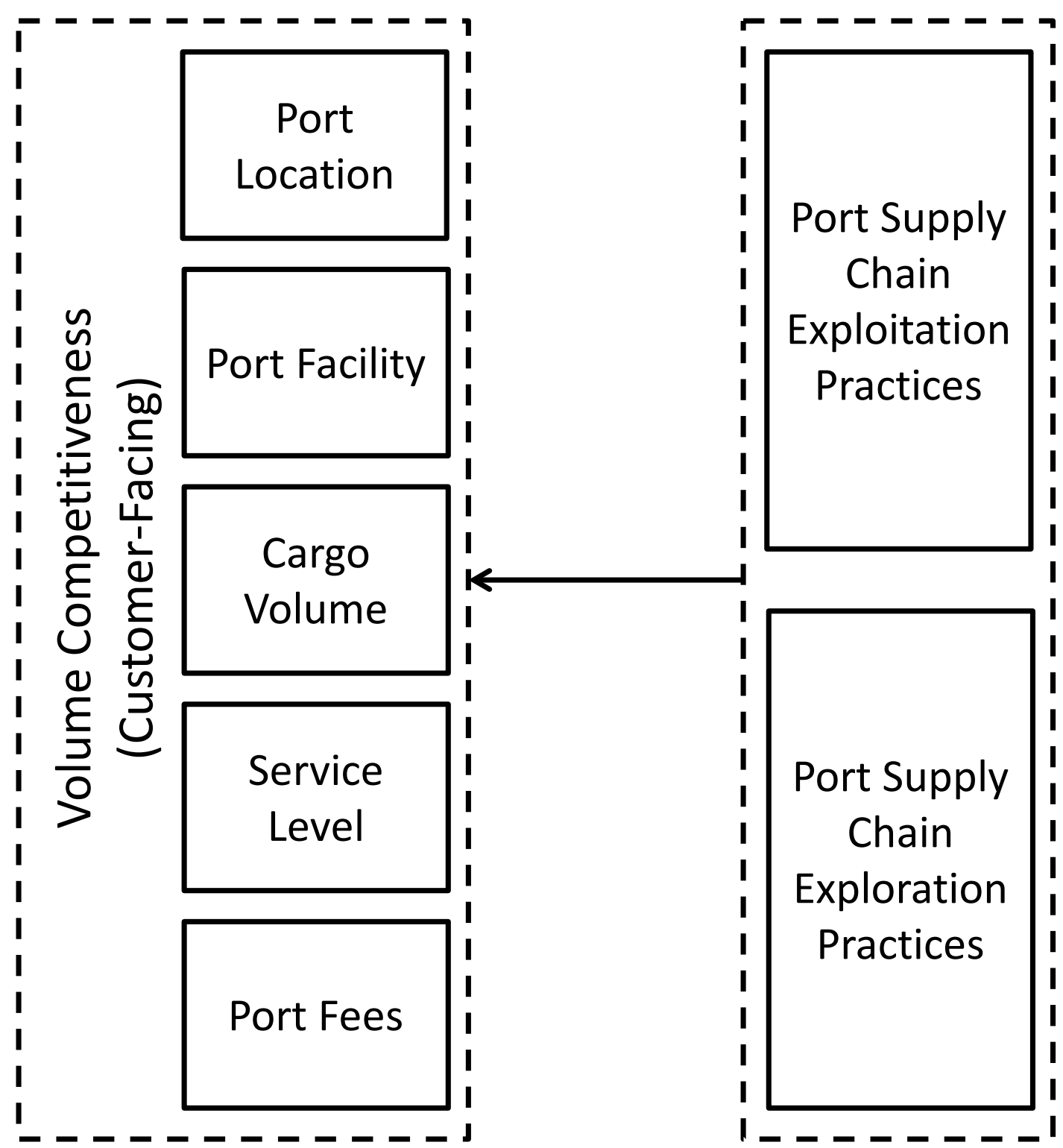

Figure 1 Balanced Theory of Port Competitiveness (BTOPC) Framework (Hales et al. 2016 and 2017) 